«Philosophy and political science in the context of modern culture», 2019, T. 11, № 2

ФІЛОСОФІЯ ТА ПОЛІТОЛОГІЯ В КОНТЕКСТІ СУЧАСНОЇ КУЛЬТУРИ

ISSN 2663-0265 (Print), ISSN 2663-0273 (Online)

Journal home page: https://fip.dp.ua/index.php/FIP

УДК 140.8

\author{
Юлія Володимирівна Пісна \\ Дніпровський начіональний університет імені Олеся Гончара \\ Пр. Гагаріна 72, Дніпро, 49000, Україна \\ E-mail: ulana88@ukr.net, ORCID ID: https://orcid.org/0000-0002-3436-2419 \\ Received 28 August 2019; revised 19 September 2019; accepted 11 October 2019
}

DOI: $10.15421 / 351914$

\title{
ПРОБЛЕМА КОНФЛІКТУ У ФІЛОСОФІЇ ЕРІХА ФРОММА
}

\section{Анотація.}

Фромівське розуміння конфлікту вирізняється впевненістю у його конструктивних наслідках i користі для суспільного розвитку. Проте така характеристика актуальна лише для істинних конфліктів, на противагу деструктивним, які породжені злоякісною агресією і ведуть до насильства та військових зіткнень. Кониепція особистості Е. Фромма базується на розумінні внутрішнього конфлікту біофілії $і$ некрофілї̈, де перевага того чи іншого визначає сутність людини. Конфлікт не патологія, а хвороба, яку можна вилікувати зниженням рівня агресії людини через творчу самореалізацію і конструктивні зміни. Людство має враховувати наявність такого потужного ресурсу задля викорінення деструктивних конфліктів із суспільної взаємодії.

Ключові слова: конфлікт, агресія, деструктивність, людина, суспільство, сочіальний характер, буття, соиіальний конфлікт, біофілія, гуманізм, творчість.

\section{Yuliya V. Pisna \\ Oles Honchar Dnipro National University \\ Gagarina ave., 72, Dnipro, 49000, Ukraine \\ E-mail: ulana88@ukr.net,ORCIDID: https://orcid.org/0000-0002-3436-2419}

A problem of conflict is in philosophy of E. Fromm

\section{Abstract.}

The analysis of philosophical works of E. Fromm gives an opportunity to draw conclusion, that principal reason of conflicts is aggression. As a nocifensor aggression is considered the fully normal phenomenon and helps personality to outline own borders, protect and save the individuality. However malignant aggression is sent to murder and violence and characteristic only for a man. She generates social contradictions - exploitation, conflicts, wars. Development of malignant aggression is inherent to those people that is not explained on development and work. They are not involved in the process of production and have a low level of education. The displays of aggression in modern society have a tendency to the increase of their frequency. Analyzing this phenomenon an author marks that aggression has two kinds that substantially differ one from other. Aggression it is possible and follow to overcome to every member of society in to the oneself. Unlike the looks of Z. Freid and K. Lorents, that count aggression in a man natural and insuperable, a philosopher considers that humanistic potential of western society yet not outspent.

Understanding of conflict of E. Fromm is distinguished by a confidence in his structural consequences and benefit for community development. However such description is actual only for veritable conflicts, in a counterbalance destructive that is descendant malignant aggression and conduce to violence and soldiery collisions. Conception of personality of E. Fromm is based on understanding of internal conflict of biophilia and necrophilia, where advantage of that or other determines essence of man. A conflict is not pathology, but illness that can be cured by the decline of level aggressions of man through creative self-realization and structural changes. Humanity must take into account the presence of such powerful resource for the sake of eradication of destructive conflicts from public cooperation.

Keywords: conflict, aggression, destructive, man, society, social character, existence, social conflict, biophilia, humanism, work. 
«Philosophy and political science in the context of modern culture», 2019, T. 11, № 2

Юлия Владимировна Писная

Днипровский нацчональный университет имени Олеся Гончара

Пр. Гагарина 72, Днипро, 49000, Украина

E-mail: ulana88@ukr.net, ORCID ID: https://orcid.org/0000-0002-3436-2419

Проблема конфликта в философии Эриха Фромма

\section{Аннотация.}

Понимание конфликта Э. Фроммом отличается уверенностью в его конструктивных следствиях и пользе для развития общества. Такая характеристика актуальна только для подлинных конфликтов, в противовес деструктивным, которые порождены злокачественной агрессией, ведут к насилию и военным столкновениям. У философа концепция личности основана на понимании личностного конфликта биофилии и некрофилии, где преобладание той или иной склонности определяет сущность человека. Конфликт не является патологией, а определен Э. Фроммом как болезнь, которую можно излечить путем снижения уровня агрессии человека через творческую самореализацию. Человечеству необходимо учесть наличие такого мощного ресурса дабы искоренить деструктивные конфликты из соичального взаимодействия.

Ключевые слова: конфликт, агрессия, деструктивность, человек, общество, сочиальный характер, бытие, сочиальный конфликт, биофилия, гуманизм, творчество.

\section{Актуальність дослідження.}

Проблема конфлікту досліджується в різних галузях гуманітарного знання. Проте методологія розуміння сутності конфлікту та підходи до вивчення даної теми довгий час формувалися та розвивалися в межах філософії. Лише у XX столітті разом 3 виникненням окремих дисциплін - соціології, психології, політології та ін. - стає очевидною специфіка конфліктологічних досліджень.

Сучасні теорії конфлікту сформовані на основі західної філософської думки. Витоки філософії конфлікту i сутність основних теоретичних підходів до розуміння даного феномену наявні у працях відомих мислителів, таких як 3. Фройд, Г. Зіммель, Л. Козер, Р. Дарендорф, Е. Фромм, М. Хоркхаймер, Г. Маркузе, К. Лоренц та ін. Всі вони аналізували сутність конфлікту, його розвиток i динаміку, особливості виникнення та можливі наслідки 3 метою розширення знань про даний феномен та його попередження в суспільстві. Таким чином на заході сформувалося певне уявлення про конфлікт, що дало поштовх розвитку конфліктології як науки.

Довгий час радянський простір був зорієнтований на «безконфліктний» розвиток суспільства, що нівелювало актуальність вивчення конфліктологічної проблематики на вітчизняних теренах. У свою чергу пострадянське суспільство виявилося не готовимдо сприйняття конфлікту, як феномену суспільного розвитку. Такий перебіг подій мав переважно деструктивні наслідки як для кожної окремої особистості так і для людства в цілому, адже для вирішення проблеми слід iii принаймні усвідомлювати.

Конфлікти пронизують все наше життя яке сповнене єдності протилежних начал, бінарних опозицій та антагонізмів. Стратегія уникнення конфліктів працює до певного часу, а потім провокує ескалацію та рух по колу затримуючи пошук шляхів вирішення суперечності.

Неможливість уникнення конфліктів показує єдиний вірний шлях у даному напрямку - їх грунтовне вивчення. Саме філософський підхід дозволяє осягнути i осмислити конфліктність буття, оскільки лише філософія продукує знання про різноманітні аспекти поведінки людини i функціонування суспільства, а також дає можливість методологічно і грунтовно аналізувати навколишню дійсність. Філософія дає можливість охопити людину в цілості з їі реальністю, не висмикуючи окремі контексти. Це дозволяє глибоко, грунтовно і конструктивно аналізувати явище, виявляти закономірності та прогнозувати розгортання подій.

В історії філософської думки мислителі 
«Philosophy and political science in the context of modern culture», 2019, T. 11, № 2

не завжди однозначно висловлювались на рахунок ролі та значення конфлікту для кожної окремої особи і для суспільства в цілому. 3 одного боку, підкреслюючи деструктивну роль конфлікту, слід зазначити, що будь-які протиріччя, зіткнення різних інтересів, цілей, прагнень та реалій, порушують стабільність та гармонію системи (як окремої особи, так i суспільства), ведуть до дестабілізації, хаосу. 3 іншого боку, конфлікт можна розглядати як конструктивні зрушення, що є запорукою розвитку людини і суспільства.

Серед закордонних психологічних досліджень конфлікту у першій половині XX ст. слід виокремити психоаналітичний напрям, засновником якого вважають 3. Фройда. Проте фройдівське розуміння конфлікту наче прирікає людину на вічну боротьбу суперечностей, як в ній самій, так i 3 ii оточенням. У свою чергу Е. Фромм разом 3 іншими неофрейдистами розширили розуміння природи i поняття конфлікту та спробували включити в нього соціальний контекст. Вивчення конфлікту на основі фромівських робіт $є$ актуальним, оскільки автор надзвичайно влучно описує і пояснює реалії сьогодення та їх можливі руйнівні наслідки для всього людства. Вивчення i розуміння динаміки цих процесів дозволить сформувати уявлення про основну ідею конфлікту сучасності та визначити шляхи руху в напрямку «конфлікт - феномен суспільного розвитку».

Отже, метою даної статті $є$ дослідження проблеми конфлікту на основі філософського аналізу робіт Е. Фромма. Мета досягається шляхом постановки i вирішення наступних завдань:

1) розкрити вплив ідей 3. Фройда на формування концепції соціального конфлікту Е. Фромма;

2) проаналізувати розуміння агресії E. Фроммом як першопричини конфліктів та окреслити перспективу їх вирішення.

\section{Основна частина.}

Розуміння природи конфліктів у філософських текстах XX століття значною мірою грунтується на психоаналітичних 26 концепціях уявлення про людину. Психоаналіз презентував людину як таку, що діє не лише під впливом свідомої мети. Відкриття реальності несвідомого належить 3. Фройду i до теперішнього часу має неабиякий вплив на психологічну методологію та практику, на розуміння сутності людського у філософських ідеях i концепціях та на сприйняття людиною самої себе i свого оточення. Сьогодні психоаналіз розуміють i як метод вивчення психічних процесів, i як вчення про несвідому природу людської душі, і як психотерапевтичну практику.

Фройдівська ідея дослідити людину виключно 3 точки зору психологї̈, відмовившись від біологічного та відкинувши будь-які спроби провести соціологічні аналогії, дала масив емпіричного матеріалу та можливість удосконалення методологічного підходу. Психодинамічна модель зв'язку психічних процесів дозволила пояснити динаміку впливу бажань і розуму, виховання і природних інстинктів. За допомогою опису свідомих і несвідомих механізмів психіки 3. Фройд створив одну із перших концепцій людської конфліктності. Більшою мірою він аналізував саме внутрішні конфлікти особистості, проте без уваги не залишилися i міжособистісні конфлікти (між батьками та дітьми, між чоловіками та жінками). Отож, за 3. Фройдом протиріччя лежить в самій людській природі. Завжди всередині людини відбувається конфлікт між інстинктивним та культурним, що породжує агресію, яка спрямовується зовні (на суспільство) або на себе.

Е. Фромм - соціальний психолог, філософ, психоаналітик, один із засновників неофрейдизму - піддає критиці ідеї 3. Фройда i розвиває їх. Мислитель вважає, що людина являє собою не лише результат психічних протиріч чи біологічно виправданих інстинктів, вона є і наслідком пристосування до соціальних умов. Тобто, за Е. Фроммом, індивідуальність людини знаходиться під впливом суспільних відносин, що втілюються у соціальному характері. Кожна епоха формує свій соціальний характер. Значна 
«Philosophy and political science in the context of modern culture», 2019, T. 11, № 2

кількість праць Е. Фромма присвячена аналізу сучасного суспільства і трансформації людини під впливом зміни соціальних обставин. Особливу увагу слід звернути на вивчення конфлікту як соціального явища. Філософ розглядає і намагається пояснити причиннонаслідкові зв'язки конфліктів всіх рівнів.

Е. Фроммакцентує увагу на конструктивних функціях конфлікту. Мислитель вважає, що конфлікт веде до катарсису, просвітлення та являється запорукою розвитку, проте не всі конфлікти $є$ конструктивними. Оскільки людина являє собоюєдність двох протилежних прагнень - біофілії і некрофілії, то в кінцевому результаті все залежить від переваги того чи іншого в ній. У випадку якщо людина більшою мірою підвладна перевазі некрофілії вона прагне до володіння і перетворює у мертве все, що стає об'єктом іiі власності. Людина тією ж мірою спроможна розвивати в собі і любов до життя, яка не може, на думку автора, повністю витіснити некрофілію, але здатна ii мінімізувати. Людство має враховувати наявність такого потужного ресурсу задля викорінення деструктивних конфліктів із суспільної взаємодії. Аби розвивати і зрощувати у собі цей ресурс людині слід бути терплячою, дисциплінованою, критично мислити, постійно навчатися, відмовитися від власного нарцисизму та боротися зі своїми сумнівними бажаннями [5, с. 210]. Е. Фромм підкреслює: «Истинные конфликты между двумя людьми, цель которых - не проекция и не прикрытие, конфликты, происходящие на глубинных уровнях внутренней реальности, где они и зарождаются, не деструктивны по своей сути. Они ведут к просветлению, к катарсису, из которого оба партнера выходят более сильными и понимающими» [8, с. 177]. Тобто, істинні конфлікти дійсно конструктивні і $є$ необхідними для оновлення, вони відбуваються стихійно, але їм притаманна повнота і цілісність.

Останнім часом конфліктність в суспільстві посилюється та характеризується своєю деструктивністю. Зростає внутрішня напруга особистості і розвивається внутрішній конфлікт. Людина сприймає себе крізь призму своєї затребуваності в системі виробництва і намагається зрощувати у собі такі якості, що допоможуть вигідніше «продати» себе. В той же час вона не прагне бачити себе творчою $\mathrm{i}$ різносторонньою особистістю, адже система ринкових відносин не передбачає цього. Е. Фромм підкреслює, що результат творчості (наприклад, картина) має цінність сама по собі. Коли ж на неї встановлюють ціну вона втрачає цінність і ми можемо говорити лише про вартість.

Людина сама для себе окреслює межі, обираючи не справжній спосіб існування в таких ринкових умовах і ставить грати, за якими унеможливлюється реальне i конструктивне життя. Це породжує агресію i нестабільний емоційний стан, що сіє ворожнечу між індивідами. У праці «Анатомія людської деструктивності» Е. Фромм детально досліджує зародження i прояв агресії у людини, як основну передумову конфліктної поведінки. Прояви агресії у сучасному суспільстві мають тенденцію до збільшення їх частоти. Аналізуючи дане явище автор наголошує, що агресія має два види, які суттєво відрізняються один від одного:

1) доброякісна агресія - виникає у ситуаціях загрози життю і спрямована на захист і оборону, активізується завдяки імпульсам, що спрямовуються на втечу або напад (в залежності від ситуації); така агресія має біологічні форми прояву і «згасає» коли зникає загроза; доброякісна агресія притаманна людині i тваринам;

2) злоякісна агресія - це деструктивність і жорстокість, притаманна лише людині, не служить біологічному пристосуванню, не має мети і філогенетичної програми.

Е. Фромм також вказує на три важливі відмінності від тварин у сприйнятті агресії людиною:

1. Людині притаманне прогностичне мислення, тому вона може сформувати уявлення не тільки про реальну загрозу, а й передбачити іiї в майбутньому.

2. Особа здатна зробити припущення щодо певної загрози у своїх думках, тобто людині 
«Philosophy and political science in the context of modern culture», 2019, T. 11, № 2

можна «навіяти» наявність небезпеки, якої насправді немає.

3. Людина здатна сприймати загрозу не лише своїм вітальним цінностям, а й інтересам (патріотизм, визнані нею ідеали, релігійні переконання тощо).

Таким чином, Е. Фромм аналізує низку особливостей людської агресії і приходить до висновку, що вона перевищує тваринну агресивність в декілька разів і має низку специфічних рис, які підкреслюють іiі небезпечність для нашого технократичного суспільства. Слід зауважити, що на думку мислителя важливим чинником, що впливає на агресивність, є відсутність освіти, через що люди не вмотивовані до нової діяльності і розвитку інтересів. Якщо ж вони не задіяні і на виробництві, то накопичення агресивності зростає не маючи можливості ії вивільнення. Так формуються прошарки населення, які можуть використати будь-який привід щоб проявити свою агресію. Це формує підгрунтя для соціальних конфліктів, політичних маніпуляцій та пригнічення одними інших.

Деструктивний характер зорієнтований на агресію, на думку Е. Фромма, - є садизм, тобто бажання одного повністю контролювати іншого. Тобто прояв орієнтиру на володіння одного іншим є садизмом, побічним ефектом ринкових відносин та не має нічого спільного з буттям, любов'ю, творчістю. Прикладом садизму може бути і тотальний контроль життя дитини батьками [9, с. 159].

Проте мислитель полемізує з К. Лоренцом i 3. Фройдом, які надають агресії статус неминучої вродженої якості людини, оскільки тоді людина спрямована або на самогубство, коли агресує на саму себе, або на вбивство інших. Е. Фромм протестує проти такої безнадійної ідеї, яка прирікає людство на агресію, що потрапляє у число інстинктів. Він наголошує на тому, що воля до життя завжди сильніша за інстинкти смерті. Природна агресивність має свої прояви лише за певних обставин і не може бути постійним чинником небезпеки. Більше того, переважання в людині конструктивних, життєздатних установок на творення знижують ступінь ii агресії, що свідчить про небезнадійність людини і людського в ній.

\section{Висновки.}

Отже, на основі аналізу низки філософських робіт Е. Фромма слід зазначити, що фундаментальною детермінантою конфліктів $є$ агресія. Як захисний механізм агресія вважається цілком нормальним явищем і допомагає особистості окреслити власні кордони, захистити та зберегти свою індивідуальність «Я». Проте злоякісна агресія спрямована на вбивство і насильство (характерна лише для людини), породжує соціальні антагонізми - експлуатацію одними інших та війни. Розвиток злоякісної агресії притаманний таким прошаркам соціуму, які не вмотивовані на саморозвиток і творчість, не задіяні у процесі виробництва та мають низький рівень освіти. Агресію можна і слід долати кожному члену соціуму щоденною кропіткою працею: тренуванням сили волі, розвитком творчості, орієнтиром на «буття» на противагу «володінню». На відміну від поглядів 3. Фройда та К. Лоренца, які вважають агресію в людині природною та нездоланною, філософ вважає, що гуманістичний потенціал західного суспільства не вичерпано. Е. Фромм ставить перед суспільством в цілому, і перед кожною людиною зокрема, глобальне завдання: змінити соціальні умови, що породжують некрофілію і створюють основи для війн та інших соціальних конфліктів. У кожної людини є природний ресурс для зрощення у собі любові до життя, що має стати метою розвитку суспільства в цілому. Конфлікт у теорії Е. Фромма не патологія, а хвороба яку можна вилікувати.

Подальшу дослідницьку перспективу має проведення структурного історикофілософського аналізу феномена конфлікту в історії філософської думки. В перспективі подальшого дослідження конфліктологічної проблематики передбачається розробка програми профілактики соціальних конфліктів на основі філософських ідей західноєвропейських мислителів. 
«Philosophy and political science in the context of modern culture», 2019, T. 11, № 2

\section{Бібліографічні посилання}

1. Дарендорф, Р. Элементы теории социального конфликта. Социс. 1994, №5 С. 142-147.

2. Фрейд, 3. Введение в психоанализ: Лекции. СПб.: Питер, 2002. 384 с.

3. Фрейд, 3. Мы и смерть. Рязанцев С. Танатология (учение о смерти). СПб.: Восточно-Европейский Институт Психоанализа, 1994. С. 13-25.

4. Фрейд, 3. Я и ОНО. 3. Фрейд. Я и оно: Сочинения. М.: ЭКСМО; Харьков: ФОЛИО, 2002. С. 839860.

5. Фромм, Э. Анатомия человеческой деструктивности. М.: Республика, 1994. 315 с.

6. Фромм, Э. Бегство от свободы; общ. Ред. П. Гуревича; пер. с англ. Г Швейника. М.: Флинта; МПСИ; Прогресс, 2006. 248 с.

7. Фромм, Э. Иметь или быть? Фромм Э. Иметь или быть? Ради любви к жизни. М.: Айрис-Пресс, 2004. $133 \mathrm{c}$.

8. Фромм, Э. Искусство любить. СПб.: Азбука-классика, 2005. 189 с.

9. Черепанова, Е. С. Философия конфликта: [учеб. пособие]. Екатеринбург: Изд-во Урал. ун-та, 2016. $196 \mathrm{c}$.

\section{References}

1. Darendorf, R. Elementy teorii socialnogo konflikta. Socis. 1994, №5 S. 142-147.

2. Frejd, Z. Vvedenie v psihoanaliz: Lekcii. SPb.: Piter, 2002. 384 s.

3. Frejd, Z. My i smert. Ryazancev S. Tanatologiya (uchenie o smerti). SPb.: Vostochno-Evropejskij Institut Psihoanaliza, 1994. S. 13-25.

4. Frejd, Z. Ya i ONO. Z. Frejd. Ya i ono: Sochineniya. M.: EKSMO; Harkov: FOLIO, 2002. S. 839-860.

5. Fromm, E. Anatomiya chelovecheskoj destruktivnosti. M.: Respublika, 1994. $315 \mathrm{~s}$.

6. Fromm, E. Begstvo ot svobody; obsh. Red. P. Gurevicha; per. s angl. G Shvejnika. M.: Flinta; MPSI; Progress, 2006. $248 \mathrm{~s}$.

7. Fromm, E. Imet ili byt? Fromm E. Imet ili byt? Radi lyubvi k zhizni. M.: Ajris-Press, 2004. 133 s.

8. Fromm, E. Iskusstvo lyubit. SPb.: Azbuka-klassika, 2005. 189 s.

9. Cherepanova, E. S. Filosofiya konflikta: [ucheb. posobie]. Ekaterinburg: Izd-vo Ural. un-ta, 2016. 196 s. 